\title{
Evaluation of degradability and ruminal kinetics of soybean meal subjected to strategies to maximize protein escape from the rumen
}

\section{Avaliação da degradabilidade e cinética ruminal de farelos de soja submetidos a estratégias para maximizar a taxa de escape de proteína do rúmen}

\author{
Mikael Neumann ${ }^{1}$; Eloize Jaqueline Aske ${ }^{2 *}$; Leslei Caroline Santos ${ }^{3}$; \\ Edelmir Silvio Stadler Junior'; Bruno José Venancio ${ }^{4}$; Giovanna Bobato \\ Pontarolo ${ }^{5}$; Fernando Braga Cristo ${ }^{5}$; Emylli Pereira e Silva ${ }^{6}$
}

\section{Highlights:}

Ruminal degradability of soybean meal treated with heat or with additives.

Soybean meal with condensed tannins decreased the ruminal protein degradation.

Support the choice of feedstuffs with higher levels of RUP in ruminant nutrition.

\begin{abstract}
The objective of this experiment was to evaluate the in situ dry matter degradability and in situ crude protein degradability of soybean meal subjected to different treatments (thermal, chemical, tannins or saponins). The treatments were: conventional soybean (CON); soybean expeller (EXP); lignosulfonatetreated soybean meal (LIGS); condensed tannin-treated soybean meal (CTAN); hydrolysable tannintreated soybean meal (HTAN) and Yucca schidigera extract-treated soybean meal (YUC). Samples of $5 \mathrm{~g}$ soybean meal were packed in nylon bags and incubated in the rumen of 2 fistulated cattle for seven incubation times $(0,3,6,9,12,18$ and 24 hours $)$, in sequence were washed, dried and weighed. The ruminal kinetics parameters were calculated, and the experiment was completely randomized, with six treatments, four replicates each, with duplicates. The EXP and LIGS treatments showed lower crude protein disappearance (CPD) within 12 hours, the CON, HTAN and YUC treatments had the highest CPD, and the CTAN presented an intermediate value $(41.84 \%)(\mathrm{P}<0.05)$. EXP had the lowest fraction "a" (soluble) of crude protein (CP) (10.1\%) followed by LIGS and CTAN (average of 14.82\%). EXP and LIGS had the highest rumen undegradable fraction of CP (57.35 and 51.62\%), respectively. In addition, ruminal disappearance rates of dry matter and CP of the treatments ranged from 2.17 to $1.36 \%$ $\mathrm{h}^{-1}$ and from 2.63 to $1.2 \% \mathrm{~h}^{-1}$, respectively. The most efficient treatments to reduce ruminal protein degradation were EXP, LIGS and CTAN.
\end{abstract}

Key words: Rumen undegradable protein. Ruminal disappearance rate. Tannins.

\footnotetext{
1 Prof. Dr., Pesquisador, Universidade Estadual do Centro Oeste, UNICENTRO, Guarapuava, PR, Brasil. E-mail: neumann. mikael@hotmail.com

2 M.e em Zootecnia, Universidade Federal do Paraná, UFPR, Curitiba, PR, Brasil. E-mail: elojaque@gmail.com

3 M.e, Discente do Curso de Doutorado do Programa de Pós-Graduação em Zootecnia, UNIOESTE, Marechal Cândido Rondon, PR, Brasil. E-mail: lesleicaroline@hotmail.com

4 Mestres em Ciências Veterinárias, UNICENTRO, Guarapuava, PR, Brasil. E-mail: edelmirjunior@hotmail.com; bru. ze.venancio@gmail.com

5 Discentes do Curso de Mestrado do Programa de Pós-Graduação em Ciências Veterinárias, UNICENTRO, Guarapuava, PR, Brasil. E-mail: giovannabpontarolo@hotmail.com; fernandobragacristo@gmail.com

6 Eng ${ }^{a}$ Agra ${ }^{a}$, Estagiária no Núcleo de Produção Animal, NUPRAN, Guarapuava, PR, Brasil. E-mail: emylli.pe95@gmail.com

* Author for correspondence
} 


\section{Resumo}

O objetivo deste trabalho foi avaliar a degradabilidade ruminal in situ da matéria seca e a degradabilidade ruminal in situ da proteína bruta de farelos de soja sob diferentes tratamentos (térmico, químico, com taninos ou saponina). Os tratamentos foram: farelo de soja convencional (CON); expeller de soja (EXP); lignossulfato (LIGS); com inclusão de taninos condensados (TANC); com taninos hidrolisáveis (TANH) e com extrato de Yucca schidigera (YUC). Amostras de $5 \mathrm{~g}$ dos farelos de soja foram acondicionadas em bolsas de náilon e incubadas em 2 bovinos canulados ruminalmente, durante sete tempos de incubação ruminal $(0,3,6,9,12,18$ e 24 horas), na sequência foram lavadas, secas e pesadas. Os parâmetros de cinética ruminal foram calculados, e o experimento foi inteiramente casualizado, com seis tratamentos, quatro repetições cada e com duplicatas. Os farelos de soja EXP e LIGS tiveram menor desaparecimento da PB (DPB) em 12 horas, já o CON, TANH e YUC as maiores DPB e TANC um valor intermediário $(41,84 \%)(\mathrm{P}<0,05)$. EXP teve a menor fração "a" (solúvel) da proteína bruta $(\mathrm{PB})(10,1 \%)$ seguido de LIGS e TANC (média de 14,82\%). EXP e LIGS tiveram maior fração indegradável no rúmen de PB $(57,35$ e $51,62 \%)$, respectivamente. E as taxas de desaparecimento ruminal da matéria seca (MS) e PB dos tratamentos variaram entre 2,17 a $1,36 \% \mathrm{~h}^{-1}$ e 2,63 a $1,2 \% \mathrm{~h}^{-1}$, respectivamente. Os tratamentos mais eficientes para diminuir a degradação proteica ruminal foram EXP, LIGS e TANC.

Palavras-chave: Proteína não degradável no rúmen. Taninos. Taxa de desaparecimento ruminal.

\section{Introduction}

Crude protein $(\mathrm{CP})$ in ruminant nutrition has two fractions, according to National Research Council [NRC] (2001), the rumen degradable protein (RDP) and the rumen undegradable protein (RUP). RDP provides peptides, free amino acids and ammonia for growth and synthesis of microbial protein, which supplies most of the amino acids for intestinal absorption. RUP is the second most important source of absorbable amino acids in the intestine (NRC, 2001). Considering the ruminal protein degradation rate, the Cornell Net Carbohydrate and Protein System (CNCPS) model divides the CP into protein fraction A: non-protein nitrogen that directly enters the rumen ammonia pool, protein fraction B1: true protein with high degradation rate, protein fraction B2: partially degraded protein in the rumen, protein fraction B3: neutral detergent insoluble protein (NDIP), slowly degraded in the rumen, and protein fraction $\mathrm{C}$ : acid detergent insoluble protein (ADIP), indigestible (Fox et al., 2004).

The protein source commonly used in dairy cattle diet is the soybean meal, due to its palatability, lysine: methionine ratio and high amino acid availability (Nakamura et al., 1992; Santos, Santos, Theurer, \&
Huber, 1998). Among the high RUP feedstuffs are heat-treated soybean meal, such as soybean expeller or with chemical treatment, such as lignosulfonatetreated soybean meal, which contains hydrolyzed xylose (Nakamura et al., 1992).

A review by Santos et al. (1998) evaluated the inclusion of lignosulfonate-treated soybean meal in dairy cattle diet, and reported increased milk yield with this ingredient in relation to cows fed conventional soybean meal. Similar findings were found in the meta-analysis of Ipharraguerre and Clark (2005), where the supply of RUP source of soy or animal origin, resulted in a greater supply of non-ammonia or microbial nitrogen reaching the small intestine, in comparison to conventional soybean meal.

Another possibility to increase the escape of CP from ruminal degradation, thus increasing the supply of amino acids to the small intestine, is the use of secondary compounds of plant metabolism, such as tannins (hydrolyzed and/or condensed) (Mathieu \& Jouany, 1993) and saponins. These compounds have been extensively used because of their antimicrobial effect, modulating rumen fermentation and improving the use of CP (Benchaar, McAllister, 
\& Chouinard, 2008). Regarding saponins, such as Yucca schidigera extract, they are known for their glucose fractions to bind with ammonia nitrogen (Benchaar et al., 2008).

Tannins can decrease ruminal protein degradation by forming indigestible complexes with proteins or microbial enzymes. Thus, a reduction in ruminal protein degradation and a lower concentration of ruminal ammonia are expected (Kozloski et al., 2012). When adding tannins to the ruminant diet, the effect is related to the source and concentration of the tannin used (González, Pabón, \& Carulla, 2002; Jayanegara, Leiber, \& Kreuzer, 2011), The best for use is tannin that promotes decreased ruminal protein degradation without affecting intestinal protein digestion (González et al., 2002).

Jayanegara et al. (2011) found a decrease in ruminal ammonia and methane emission with increasing tannin dosage. Mathieu and Jouany (1993) verified decreased in vitro protein degradation of soybean meal, without altering the production of microbial metabolites, with hydrolyzable tannins in concentrations of 0.2 and $1.1 \%$ in the diet. And Kozloski et al. (2012) tested increasing doses of hydrolyzable tannins (Acacia mearnsii) and observed a decrease in the nitrogen excretion via urine. In this context, the use of tannins as additives, increases the efficiency of nitrogen use and decreases nitrogen excretion, thus reducing environmental contamination (Powell, Aguerre, \& Wattiaux, 2011).

Considering the treatments of soybean meal with heat (soybean expeller, EXP), chemical compounds (lignosulfonate-treated soybean meal, LIGS), with tannins (condensed, CTAN or hydrolyzable, HTAN) or saponins (Yucca schidigera extract, YUC) which aim to reduce ruminal degradability of protein fractions, the present study aimed to evaluate the ruminal disappearance of dry matter and $\mathrm{CP}$, and the kinetic parameters of soybean meal under different treatments, for to observe if the treatments were effective in decreasing ruminal degradability of crude protein.

\section{Material and Methods}

The experiment was conducted by the Núcleo de Produção Animal (NUPRAN) at the Universidade Estadual do Centro-Oeste (UNICENTRO), in Guarapuava, State of Paraná. The experimental procedures were approved by the Ethics Committee on the Use of Animals (CEUA/UNICENTRO) under number 011/2019.

The objective was to evaluate six treated soybean meals, in relation to chemical composition, ruminal kinetics, ruminal disappearance rate and dry matter disappearance (DMD) and crude protein disappearance (CPD) within 12 or 24 hours. The evaluated soybean meals were the conventional $(\mathrm{CON})$, soybean meal after chemical treatment with lignosulfonate (LIGS), after heat treatment in the soybean expeller (EXP), treatment with condensed tannins (CTAN), with hydrolyzable tannins (HTAN), and treatment with saponin, soybean meal with Yucca schidigera extract (YUC).

Conventional soybean meal was obtained from the Agrária Cooperativa Agroindustrial, Brasil. LIGS and EXP soybean meals were commercial products, and LIGS was produced from conventional soybean meal with $46 \% \mathrm{CP}$, heated again and added with liquid sodium lignosulfonate resin 5\% (rich in xylose) (Soypass BR, lignosulfonate-treated soybean meal, Cargill Animal Nutrition ${ }^{\circledR}$, Brasil). And the EXP came from processing soybean under controlled high temperature and pressure, without the use of solvents for oil extraction, such conditions increase the level of RUP (Quality, Brasil).

CTAN, HTAN and YUC treatments were constituted by mixing conventional soybean meal with commercial additives in a $1.5 \%$ dosage, in a stainless-steel mixer, type "Y", at the Laboratório de Análises de Alimentos e Nutrição de Ruminantes of NUPRAN. CTAN was obtained by mixing soybean meal with condensed tannins (CT), with $76 \%$ tannins extracted from quebracho (Silvafeed Bypro/BPR ${ }^{\circledR}$, quebracho and chestnut tannins, Silvateam, Peru); HTAN was obtained by mixing 
conventional soybean meal with hydrolyzable tannins (HT) (Valopro ${ }^{\circledR}$; essential oils of carvacrol and cinnamaldehyde, mineral salts, acacia and chestnut tannins; Salus; Brasil); and YUC was obtained by mixing conventional soybean meal with a saponin-based product (VivActiv 'Rumiviv ${ }^{\circledR}$; Yucca schidigera extract, manganese, zinc, sodium, calcium and vitamin B1; Ibersan; Brasil).

For chemical analysis, samples were weighed and pre-dried in a forced air oven at $55{ }^{\circ} \mathrm{C}$ for 72 hours and ground in a Wiley mill (1 $\mathrm{mm}$ sieve). Subsequently, the total DM was determined in an oven at $105^{\circ} \mathrm{C}, \mathrm{CP}$ was determined by the micro Kjeldahl method, ashes by incineration at $550{ }^{\circ} \mathrm{C}(4$ hours) and fat, according to Association of Official Analytical Chemists [AOAC] (1995). The neutral detergent fiber (NDF) content was determined according to Van Soest, Roberttson and Lewis (1991), using thermostable $\alpha$ amylase, and non-fiber carbohydrates (NFC) content was obtained by the equation: NFC, $\%=100-(\%$ ash $+\% \mathrm{CP}+\%$ fat + $\% \mathrm{NDF})$. Table 1 lists the average values, resulting from the chemical analysis of the tested soybean meals.

\section{Table 1}

Chemical composition of conventional soybean meal (CON), soybean expeller (EXP), lignosulfonate-treated soybean meal (LIGS), soybean meal treated with condensed tannins (CTAN), soybean meal treated with hydrolyzable tannins (HTAN) and soybean meal treated with Yucca schidigera (YUC)

\begin{tabular}{lcccccc}
\hline \multicolumn{1}{c}{ Items } & Conventional & $\begin{array}{c}\text { Soybean } \\
\text { expeller }\end{array}$ & Lignosulfonate & $\begin{array}{c}\text { Condensed } \\
\text { tannins }\end{array}$ & $\begin{array}{c}\text { Hydrolyzable } \\
\text { tannins }\end{array}$ & $\begin{array}{c}\text { Yucca } \\
\text { schidigera }\end{array}$ \\
\hline $\mathrm{DM}(\%)$ & 88.68 & 90.88 & 90.60 & 89.00 & 89.07 & 89.04 \\
$\mathrm{Ash}^{1}$ & 5.47 & 6.18 & 5.83 & 6.08 & 5.75 & 5.46 \\
$\mathrm{Fat}^{1}$ & 1.94 & 7.96 & 2.03 & 2.35 & 2.34 & 1.91 \\
$\mathrm{CP}^{1}$ & 46.11 & 41.04 & 46.38 & 44.82 & 45.57 & 45.22 \\
$\mathrm{NDF}^{1}$ & 12.79 & 19.14 & 16.6 & 12.09 & 12.61 & 12.45 \\
$\mathrm{NFC}^{1}$ & 33.69 & 25.68 & 29.08 & 34.66 & 33.73 & 34.96 \\
\hline
\end{tabular}

${ }^{1}$ percentage in dry matter.

DM: dry matter; CP: crude protein; NDF: neutral detergent fiber; NFC: non-fiber carbohydrates.

The in situ degradability of the DM and CP (Nocek, 1997) of the feedstuffs was carried out in two Jersey castrated male cattle, with permanent ruminal cannula, with an average weight of 650 $\mathrm{kg}$, adapted to the diet with $70 \%$ corn silage and $30 \%$ pelleted concentrate, supplied twice daily.
Diet was supplied as a total mixed ration (TMR). And the concentrate was obtained from the Agrária Cooperativa Agroindustrial, Guarapuava, Paraná, Brasil. Table 2 lists the nutritional levels of the TMR, corn silage and concentrate. 
Table 2

Chemical composition of corn silage, commercial concentrate and total mixed ration (TMR) provided to animals with ruminal cannula, on a dry matter (DM) basis

\begin{tabular}{lccc}
\hline \multicolumn{1}{c}{ Composition } & Corn silage & Concentrate $^{1}$ & Total mixed ration $^{1}$ \\
\hline Dry matter, \% & 28.99 & 90.40 & 47.41 \\
Ash, \% DM & 2.85 & 8.43 & 4.52 \\
Crude protein, \% DM & 7.54 & 21.35 & 11.68 \\
Fat, \% DM & 2.99 & 2.92 & 2.97 \\
Neutral detergent fiber, \% DM & 47.05 & 24.72 & 40.35 \\
Acid detergent fiber, \% DM & 26.61 & 8.65 & 21.22 \\
Lignin, \% DM & 3.68 & 1.40 & 3.00 \\
Ca, \% & 0.15 & 1.49 & 0.55 \\
P, \% & 0.23 & 0.51 & 0.31 \\
Total digestible nutrients, \% & 69.21 & 80.90 & 72.72 \\
\hline
\end{tabular}

${ }^{1}$ Commercial concentrate based on soybean meal, wheat bran, corn grain, malt root, calcitic limestone, dicalcium phosphate, urea, salt, mineral-vitamin mix. Guarantee levels per kg concentrate: 16,000 IU vitamin A; 2,000 IU vitamin D3; 25 IU vitamin E; 0.36 g S; 0.74 g Mg; 3.6 g Na; $0.52 \mathrm{mg} \mathrm{Co} ; 22.01 \mathrm{mg} \mathrm{Cu} ; 1.07 \mathrm{mg} \mathrm{I} ; 72.80 \mathrm{mg} \mathrm{Mn} ; 0.64 \mathrm{mg} \mathrm{Se}$; $95.20 \mathrm{mg} \mathrm{Zn}$ and $40 \mathrm{mg}$ monensin.

For ruminal incubation, the ingredients were predried and ground, then $5 \mathrm{~g}$ samples were weighed and packed in nylon bags $(10 \mathrm{~cm} \times 12 \mathrm{~cm}$, with $50 \mu$ porosity). The bags were sealed, attached to a nylon thread and lead weight (100 g) at the end, according to the methodology of Goes et al. (2010). Ruminal incubation was done with the introduction of the bags into the rumen of both animals, simultaneously, following a decreasing order of time $(0,3,6,9,12$, 18 and 24 hours). Blank bags were included, and samples at time 0 were incubated for 5 minutes before removing all bags to determine the soluble fraction. After removal, all samples were immersed in icy water for 20 minutes to stop ruminal microbial activity. Then, the bags were washed, including those with 0 incubation time, dried in a forced air oven at $55^{\circ} \mathrm{C}$ for 72 hours and weighed.

The difference between pre-incubation and post-incubation weight allowed to assess the disappearance of DM and CP using the following equations: $\mathrm{DMD}=(\mathrm{DMi}-\mathrm{DMr}) /(\mathrm{DMi} * 100)$; $\mathrm{CPD}=(\mathrm{CPi}-\mathrm{CPr}) /(\mathrm{CPi} * 100)$. Where DMD and CPD correspond to the dry matter and crude protein disappearance (\%), respectively; DMi and
CPi: initial pre-incubation weight of DM and CP, respectively; DMr and CPr: residue post-incubation weight of DM and $\mathrm{CP}$, respectively (Goes et al., 2010).

The kinetic parameters, for both DM and $\mathrm{CP}$, were estimated as proposed by Orskov and McDonald (1979), where PD $=a+b\left(1-e^{-c t}\right)$ in which PD is the potential ruminal degradability of feedstuff; "a" is the soluble fraction corresponding to 0 hours of incubation; "b" is the potentially degradable fraction in the rumen corresponding to 24 hours of incubation subtracting from the fraction "a", which would be degraded at a rate "c"; "c" is the ruminal disappearance rate of fraction " $b$ "; and " $t$ " is the incubation time in hours. The non-degradable fraction in the rumen, considered non-degradable (I) was calculated using the following formula: $\mathrm{I}=$ 100 - $(\mathrm{a}+\mathrm{b})$ (Goes et al., 2010).

The experimental design was completely randomized, consisting of six treatments, with four repetitions, repeated in the fistulated animal. Data collected for each variable were tested by analysis of variance and then, when a difference was detected, Tukey's test was applied to compare 
multiple means at 5\% significance, using the statistical software SAS (Statistical Analysis System Institute [SAS Institute], 1993). Data of the disappearance rate of $\mathrm{DM}$ and $\mathrm{CP}$ were made for Proc Reg regression analysis in the same statistical program. The analysis of each variable followed the statistical model: $\left(\mathrm{Y}_{\mathrm{ijk}}=\mu+\mathrm{T}_{\mathrm{i}}+\mathrm{A}_{\mathrm{j}}+\mathrm{Rk}(\mathrm{T} * \mathrm{~A}) \mathrm{ij}+\right.$ $E_{i j k l}$ ) where: $Y_{i j k l}=$ variables dependent on feedstuff curve "i" for animal " $j$ "; $\mu=$ overall mean of all observations; $\mathrm{T}_{\mathrm{i}}=$ effect of soybean meal treatment of order "i $\mathrm{i}$ "; $A_{j}=$ effect of fistulated animal of order "j”; $R k\left(T^{*} A\right) i j=$ random effect based on repetition within the interaction between the i-th treatment of soybean meal and the $\mathrm{j}$-th fistulated animal and $\mathrm{E}_{\mathrm{ijkl}}=$ residual random effect.

\section{Results and Discussion}

The EXP and LIGS soybean meals had the lowest DMD in the periods of 12 and 24 hours (P $<0.05)$. YUC soybean meal was similar to $\mathrm{CON}$ in DMD at 12 and 24 hours (60.28 and 83.31\%, respectively), both treatments with the highest DMD rates (Table 3 ).

\section{Table 3}

Dry matter disappearance (DMD) and crude protein disappearance (CPD) of conventional soybean meal (CON), soybean expeller (EXP), lignosulfonate-treated soybean meal (LIGS), soybean meal treated with condensed tannins (CTAN), soybean meal treated with hydrolyzable tannins (HTAN) and soybean meal treated with Yucca schidigera (YUC)

\begin{tabular}{cccccccc}
\hline Items & Time $^{1}$ & Conventional & $\begin{array}{c}\text { Soybean } \\
\text { expeller }\end{array}$ & Lignosulfonate & $\begin{array}{c}\text { Condensed } \\
\text { tannins }\end{array}$ & $\begin{array}{c}\text { Hydrolyzable } \\
\text { tannins }\end{array}$ & $\begin{array}{c}\text { Yucca } \\
\text { schidigera }\end{array}$ \\
\hline \multirow{2}{*}{ DMD } & $12 \mathrm{~h}$ & $59.70 \mathrm{a}$ & $46.57 \mathrm{c}$ & $46.75 \mathrm{c}$ & $57.80 \mathrm{~b}$ & $56.45 \mathrm{~b}$ & $60.85 \mathrm{a}$ \\
& $24 \mathrm{~h}$ & $84.53 \mathrm{a}$ & $61.93 \mathrm{c}$ & $61.84 \mathrm{c}$ & $75.44 \mathrm{~b}$ & $77.80 \mathrm{~b}$ & $82.08 \mathrm{a}$ \\
\hline \multirow{2}{*}{$\mathrm{CPD}$} & $12 \mathrm{~h}$ & $54.06 \mathrm{a}$ & $29.40 \mathrm{c}$ & $34.30 \mathrm{c}$ & $41.84 \mathrm{~b}$ & $50.10 \mathrm{a}$ & $53.50 \mathrm{a}$ \\
& $24 \mathrm{~h}$ & $77.20 \mathrm{a}$ & $42.65 \mathrm{~d}$ & $48.38 \mathrm{c}$ & $64.99 \mathrm{~b}$ & $74.11 \mathrm{ab}$ & $75.31 \mathrm{a}$ \\
\hline
\end{tabular}

Mean values followed by different lowercase letters, in the same row, are significantly different by Tukey's test at $5 \%$.

${ }^{1}$ Ruminal incubation time (hours).

After 12 hours of incubation, the EXP and LIGS soybean meals showed superiority in supporting the rumen environment, and they were equivalent $(\mathrm{P}<0.05)$ presenting the lowest $\mathrm{CPD}$ rate (average of $31.85 \%$ ) (Table 3). HTAN and YUC soybean meals did not differ statistically from conventional soybean meal (average of 52.55\%) and they showed the highest CPD rates. CTAN presented an intermediate value $(41.84 \%)$. When considering the 24 hours, treatment EXP had a lower CPD than all other treatments $(42.65 \%)$.

The tannin treatments (CTAN and HTAN) had an intermediate DM ruminal disappearance between the CON and the EXP and LIGS soybean meals (Table
3), indicating that there was an effect of including tannins, and in non-experimental conditions, this strategy could increase the escape of nutrients from the rumen. Similar results were reported by Benchaar et al. (2008) with the inclusion of tannins of $0.64 \%$ in the DM intake (providing $0.45 \% \mathrm{CT}$ ). In this study, the inclusion of tannins decreased the effective ruminal degradability of DM compared to the control $(67.2$ vs $70 \%)$ with a trend $(\mathrm{P}=0.13)$ to reduce the effective ruminal degradability of $\mathrm{CP}$ (52.9 vs 57.6\%), which is consistent with the trend $(\mathrm{P}=0.09)$ of treatment with tannins to decrease the concentration of ammonia nitrogen in the rumen. Still in Benchaar et al. (2008) study, the 
use of Yucca schidigera extract did not affect the concentration of ammonia nitrogen in the rumen, despite the glycofractions of this saponin being known to bind with ammonia. In the present study, the YUC treatment showed no difference in relation to the control for all evaluated parameters.

Benchaar et al. (2008) still claim that limited results in digestion and rumen fermentation can be found due to low concentrations of the compounds used. In soybean meals HTAN and YUC, the additives of these treatments contain several ingredients in their formulations, in addition to the tannins and Yucca schidigera extract, respectively, which may have diluted these compounds and reduced the function of protein complexation. Therefore, these treatments had a CPD behavior similar to conventional soybean meal. In the research of González et al. (2002), chestnut tannins (HT) included in soybean meal resulted in a reduction in ammonia concentration in in vitro tests, compared to quebracho tannins (CT), showing that chestnut tannins were more efficient in reducing the in vitro ruminal protein degradation, a result different from the present study, in which CTAN had lower ruminal degradability.

However, results found by Jayanegara et al. (2011) showed that the inclusion of tannins decreased organic matter digestibility $(\mathrm{P}<0.01$, $\left.\mathrm{R}^{2}=0.60\right)$ and crude protein apparent digestibility $\left(\mathrm{P}<0.001, \mathrm{R}^{2}=0.78\right)$. Beauchemin, Mcginn, Martinez and McAllister (2007) evaluated the supply of 1 or $2 \%$ CT in the DM (providing 0.9 or $1.8 \% \mathrm{CT}$ ) verified a decrease in crude protein apparent digestibility, indicating that the postruminal availability of amino acids can be reduced. While the results obtained by Kozloski et al. (2012) on ruminally or duodenally cannulated sheep, with inclusion of Acacia mearnsii tannins in 0,2 , 4 or $6 \%$ of DM intake showed a linear decrease $(\mathrm{P} \leq 0.05)$ of organic matter and dietary nitrogen ruminal degradability with increased inclusion of tannins, but the duodenal flow of total nitrogen, non-ammonia or microbial nitrogen did not differ between treatments.

Treatments EXP and LIGS had lower soluble fraction "a" of DM compared to the other treatments. As for the solubilization of CP, EXP showed the lowest index $(10.10 \%)$, followed by LIGS and CTAN (average of 14.82\%), and HTAN and YUC were similar to conventional soybean meal (average of $18.19 \%$ ) (Table 4 ).

EXP and LIGS had lower " $b$ " fraction and higher "I" fraction of CP among the evaluated treatments, indicating that the crude protein had lower ruminal degradation, which was expected, due to the processing of these products in the industry. CON, HTAN and YUC, on the other hand, had higher " $b$ " fraction and lower "I" fractions of CP, which indicate greater protein degradability in the rumen, contrary to the previously described. Again, treatment CTAN had an intermediate value.

The soybean expeller was evaluated by Broderick (1986), where in vitro nitrogen solubility of conventional soybean meal was 27.22 and $27.26 \%$ for two methodologies, while the nitrogen solubility of soybean expeller was 6.44 and 5.96\%. And the estimated ruminal escape rate of $\mathrm{CP}$ was $39 \%$ for conventional soybean meal and $64 \%$ for the soybean expeller. Despite the smaller amplitude differences in the present experiment, the same pattern was observed, where the solubility (fraction "a") of CP was 43.2\%, lower in EXP than in CON. Broderick (1986) also demonstrated a decrease in ruminal ammonia nitrogen when provided soybean expeller in the diet instead of conventional soybean meal for ruminally cannulated cows (5.61 vs 8.34 $\mathrm{mg} \mathrm{dL}^{-1}$ ), and blood urea was lower (4.67 vs 6.49 $\mathrm{mmol} \mathrm{L}-1)$

Lignosulfonate-treated soybean meal was evaluated by Nakamura et al. (1992) on a 13\% CP diet for dairy cows with inclusion of $6.8 \%$ in $\mathrm{DM}$ intake, compared to the $16 \% \mathrm{CP}$ diet with $13.5 \%$ soybean meal in DM intake. The authors found no 
differences in milk yield $\left(23.75 \mathrm{~kg} \mathrm{day}^{-1}\right)$, fat and protein content in milk (3.75 and $2.86 \%$ ), yields of milk corrected for $3.5 \%$ fat $\left(38.3 \mathrm{~kg} \mathrm{day}^{-1}\right)$ and milk corrected for $3.5 \%$ fat: dry matter intake ratio $\left(1.61 \mathrm{~kg} \mathrm{~kg}^{-1}\right)$ between treatments. In this case, it is inferred that lignosulfonate-treated soybean meal is a good supply of RUP, indirectly verified in the present study by a lower CPD (Table 3 ) and a greater ruminal indigestible fraction (Table 4). In the work of Nakamura et al. (1992), even with the decrease in dietary protein, lignosulfonate-treated soybean meal was still sufficient to supply the demands of amino acids in the intestine, and maintain the productive level.

Regarding the inclusion of tannins or saponin in soybean meal, the treatment with the best effect in limiting ruminal protein degradation was CTAN, which decreased fraction " $b$ " and increased fraction "I" in comparison to CON, and it had fraction "a" similar to LIGS. Such effect may have occurred due to the formation of complexes between tannin and the substrate (proteins), considering that the evaluated additive contains good concentrations of quebracho and chestnut tannins. Powell et al. (2011) tested the same product when feeding dairy cows in different dosages $(0,0.45,0.9$ and $1.8 \%)$ and found that the release of ammonia from the manure of supplemented cows was lower in 11, 19 and $27 \%$, with dose increase compared to control, respectively. This was due to the ability of tannins to reduce the urea nitrogen excretion when consumed via diet.

\section{Table 4}

In situ degradation kinetics of DM and CP of conventional soybean meal (CON), soybean expeller (EXP), lignosulfonate-treated soybean meal (LIGS), soybean meal treated with condensed tannins (CTAN), soybean meal treated with hydrolyzable tannins (HTAN) and soybean meal treated with Yucca schidigera (YUC)

\begin{tabular}{ccccccc}
\hline Fraction & Conventional & $\begin{array}{c}\text { Soybean } \\
\text { expeller }\end{array}$ & Lignosulfonate & $\begin{array}{c}\text { Condensed } \\
\text { tannins }\end{array}$ & $\begin{array}{c}\text { Hydrolyzable } \\
\text { tannins }\end{array}$ & $\begin{array}{c}\text { Yucca } \\
\text { schidigera }\end{array}$ \\
\hline & & \multicolumn{5}{c}{$\% \mathrm{DM}$} \\
$\mathrm{a}, \%$ & $33.67 \mathrm{a}$ & $26.18 \mathrm{~b}$ & $28.25 \mathrm{~b}$ & $33.47 \mathrm{a}$ & $31.98 \mathrm{a}$ & $32.81 \mathrm{a}$ \\
$\mathrm{b}, \%$ & $50.85 \mathrm{a}$ & $35.75 \mathrm{c}$ & $33.58 \mathrm{c}$ & $41.97 \mathrm{~b}$ & $45.82 \mathrm{ab}$ & $49.27 \mathrm{a}$ \\
$\mathrm{I}, \%$ & $15.47 \mathrm{c}$ & $38.07 \mathrm{a}$ & $38.16 \mathrm{a}$ & $24.56 \mathrm{~b}$ & $22.20 \mathrm{~b}$ & $17.92 \mathrm{c}$ \\
$\mathrm{c}, \% \mathrm{~h}^{-1}$ & $2.17 \mathrm{a}$ & $1.46 \mathrm{c}$ & $1.36 \mathrm{c}$ & $1.69 \mathrm{~b}$ & $1.80 \mathrm{~b}$ & $2.08 \mathrm{a}$ \\
\hline & & \multicolumn{7}{c}{$\% \mathrm{CP}$} \\
$\mathrm{a}, \%$ & $17.78 \mathrm{a}$ & $10.10 \mathrm{c}$ & $14.47 \mathrm{~b}$ & $15.17 \mathrm{~b}$ & $17.84 \mathrm{a}$ & $18.94 \mathrm{a}$ \\
$\mathrm{b}, \%$ & $59.42 \mathrm{a}$ & $32.55 \mathrm{c}$ & $33.91 \mathrm{c}$ & $49.81 \mathrm{~b}$ & $56.27 \mathrm{a}$ & $58.11 \mathrm{a}$ \\
$\mathrm{I}, \%$ & $22.80 \mathrm{c}$ & $57.35 \mathrm{a}$ & $51.62 \mathrm{a}$ & $35.01 \mathrm{~b}$ & $25.89 \mathrm{bc}$ & $22.95 \mathrm{c}$ \\
$\mathrm{c}, \% \mathrm{~h}^{-1}$ & $2.63 \mathrm{a}$ & $1.20 \mathrm{c}$ & $1.40 \mathrm{c}$ & $1.99 \mathrm{~b}$ & $2.37 \mathrm{ab}$ & $2.44 \mathrm{a}$ \\
\hline
\end{tabular}

Mean values followed by different lowercase letters, in the same row, are significantly different by Tukey's test at $5 \%$. a: soluble fraction; b: potentially degradable fraction in the rumen; I: non-degradable fraction in the rumen.

The DM ruminal disappearance rate of treatments (Figure 1) varied $(\mathrm{P}<0.0001)$ according to the time of ruminal exposure. On average, $\mathrm{CON}$ and YUC soybean meals had the highest DM ruminal disappearance rate (fraction "c") (2.17 and 2.08\% $\left.\mathrm{h}^{-1}\right)$, respectively, followed by HTAN $\left(1.80 \% \mathrm{~h}^{-1}\right)$,
CTAN $\left(1.69 \% \mathrm{~h}^{-1}\right)$ and the EXP and LIGS, with the lowest rates ( 1.46 and $1.36 \% \mathrm{~h}^{-1}$ ), respectively (Table 4). Emphasizing that EXP and LIGS had the lowest initial disappearance with $28.32 \%$ and $29.44 \%$, respectively, compared to the other treatments. 
Corroborating data found, the in situ nitrogen degradation was also lower for the soybean expeller compared to conventional soybean meal $(0.145$ vs $0.237 \mathrm{~h}^{-1}$ ), respectively (Broderick, 1986). The inclusion of $0.4 \% \mathrm{CT}$ in the diet for cannulated animals fed soybean meal decreased the CP digestion rate (3.05 vs 1.26), compared to the control. There was also an improvement in the metabolizable protein: $\mathrm{CP}$ ratio with the inclusion of $\mathrm{CT}$ in the diet compared to the control (46.54 vs 58.69), indicating an improvement in the efficiency of $\mathrm{CP}$ use of $26 \%$. When included to soybean meal, CT decreased ruminal degradability and $\mathrm{CP}$ digestion rate, and increased $(\mathrm{P}<0.10)$ the flow of RUP and metabolizable protein (Mezzomo et al., 2011).

The CP ruminal disappearance of different soybean meals (Figure 2$)$ also varied $(\mathrm{P}<0.0001)$ according to the time of ruminal exposure. CON and YUC were higher $\left(2.63\right.$ and $\left.2.43 \% \mathrm{~h}^{-1}\right)$ than the others, followed by HTAN $\left(2.37 \% \mathrm{~h}^{-1}\right)$, CTAN $\left(1.99 \% \mathrm{~h}^{-1}\right)$, LIGS $\left(1.40 \% \mathrm{~h}^{-1}\right)$ and EXP $(1.20 \%$ $\left.\mathrm{h}^{-1}\right)$. The YUC treatment had the highest initial disappearance of CP, with $19.01 \%$.

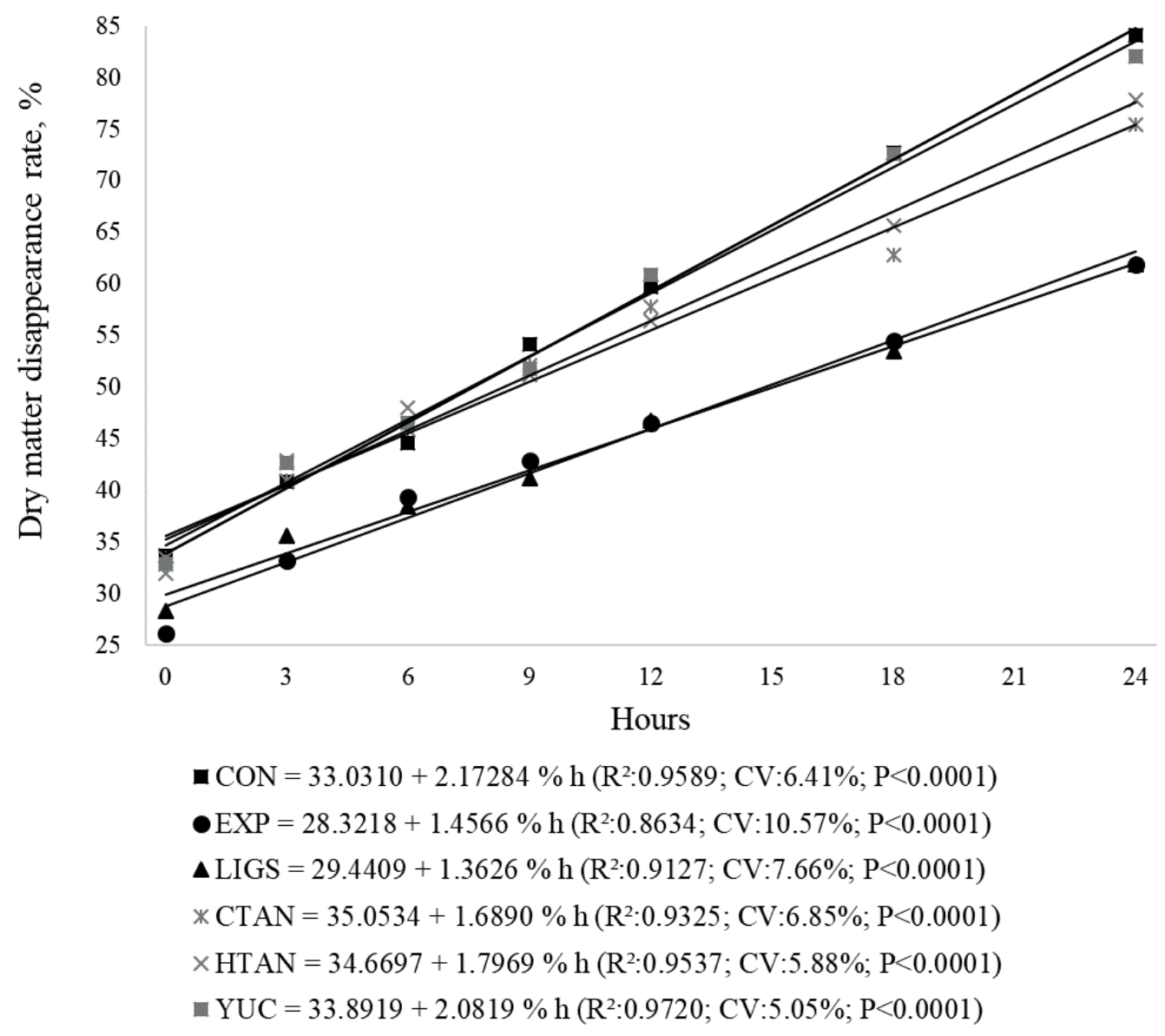

Figure 1. Dry matter ruminal disappearance rate $\left(\% \mathrm{~h}^{-1}\right)$ of conventional soybean meal $(\mathrm{CON})$, soybean expeller (EXP), lignosulfonate-treated soybean meal (LIGS), soybean meal treated with condensed tannins (CTAN), soybean meal treated with hydrolyzable tannins (HTAN) and soybean meal treated with Yucca schidigera (YUC). 


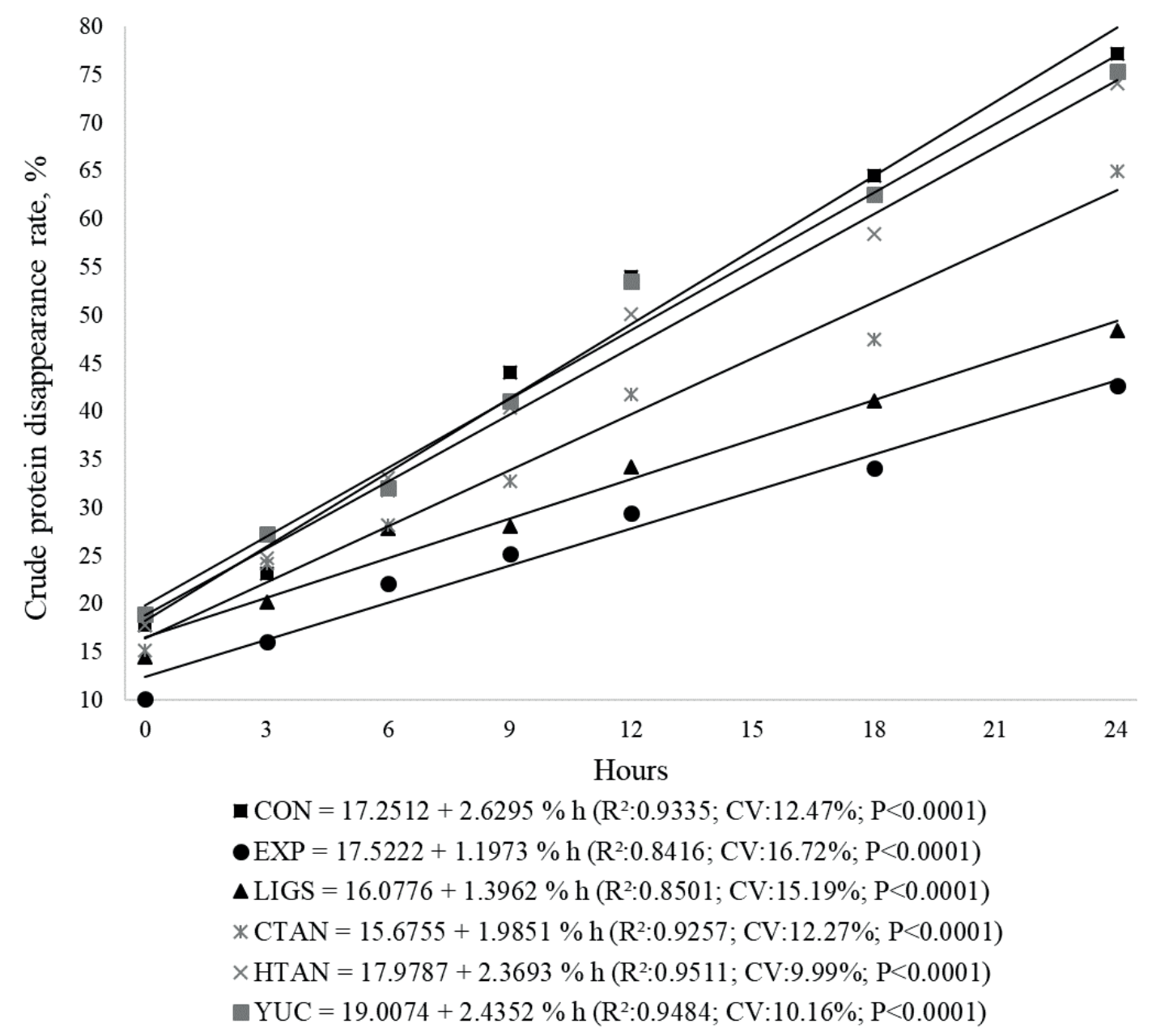

Figure 2. Crude protein ruminal disappearance rate $\left(\% \mathrm{~h}^{-1}\right)$ of conventional soybean meal (CON), soybean expeller (EXP), lignosulfonate-treated soybean meal (LIGS), soybean meal treated with condensed tannins (CTAN), soybean meal treated with hydrolyzable tannins (HTAN) and soybean meal treated with Yucca schidigera (YUC).

\section{Conclusions}

The thermal processing of the soybean expeller and the chemical treatment with lignosulfonate guarantee protection from the ruminal protein degradation, verified by the low ruminal disappearance of the DM and CP. Among the additives tested for reducing the $\mathrm{CP}$ ruminal degradability, stands out the condensed tannin base product (CTAN), which was different from conventional soybean meal in most of the evaluated parameters.

\section{References}

Association of Official Analytical Chemists (1995). Official methods of analysis. Washington D. C.: Association of Official Analytical Chemists.

Beauchemin, K. A., Mcginn, S. M., Martinez, T. F., \& McAllister, T. A. (2007). Use of condensed tannin extract from quebracho trees to reduce methane emissions from cattle. Journal Animal Science, 85(8), 1990-1996. doi: 10.2527/jas.2006-686

Benchaar, C., McAllister, T. A., \& Chouinard, P. Y. (2008). Digestion, ruminal fermentation, ciliate protozoal populations, and milk production from dairy cows fed cinnamaldehyde, quebracho condensed tannin, or Yucca schidigera saponin extracts. Journal of Dairy Science, 91(12), 4765-4777. doi: 10. 3168/ jds.2008-1338 
Broderick, G. A. (1986). Relative value of solvent and expeller soybean meal for lactating dairy cows. Journal of Dairy Science, 69(11), 2948-2958. doi: 10.3168/jds.S0022-0302(86)80751-2

Fox, D. G., Tedeschi, L. O., Tylutki, T. P., Russell, J. B., Van Amburgh, M. E., Chase, L. E., Overton, T. R. (2004). The Cornell Net Carbohydrate and Protein System model for evaluating herd nutrition and nutrient excretion. Animal Feed Science and Technology, 112(1-4), 29-78. doi: 10.1016/j. anifeedsci. 2003.10.006

Goes, R. H. T. B., Souza, K. A., Patussi, R. A., Cornelio, T. C., Oliveira, E. R., \& Brabes, K. C. S. (2010). Degradabilidade in situ dos grãos de crambe, girassol e soja, e de seus coprodutos em ovinos. Acta Scientiarum Animal Sciences, 32(3), 271-277. doi: 10.4025/actascianimsci.v32i3.7913

González, S., Pabón, M. L., \& Carulla, J. (2002). Effects of tannins on in vitro ammonia release and dry matter degradation of soybean meal. Archivos Latinoamericanos de Producción Animal, 10(2), 97-101. https://www.semanticscholar.org/ paper/Effects-of-tannins-on-in-vitro-ammoniarelease-and-Gonz\% C3\%A1lez-Pab\%C3\%B3n/ cf795e9986a839edb67335d92dce258698ae6445

Ipharraguerre, I. R., \& Clark, J. H. (2005). Impacts of the source and amount of crude protein on the intestinal supply of nitrogen fractions and performance of dairy cows. Journal of Dairy Science, 88(E. Suppl.), 22-37. doi: 10.3168/jds.S0022-0302(05)73134-9

Jayanegara, A., Leiber, F., \& Kreuzer, M. (2011). Metaanalysis of the relationship between dietary tannin level and methane formation in ruminants from in vivo and in vitro experiments. Journal of Animal Physiology and Animal Nutrition, 96(3), 365-375. doi: 10.1111/j.1439-0396.2011.01172.x

Kozloski, G. V., Harter, C. J., Hentz, F., Ávila, S. C., Orlandi, T., \& Stefanello, C. M. (2012). Intake, digestibility and nutrients supply to wethers fed ryegrass and intraruminally infused with levels of Acacia mearnsii tannin extract. Small Ruminant Research, 106(2-3), 125-130. doi: 10.1016/j. smallrumres.2012.06.005

Mathieu, F., \& Jouany, J. (1993). Effect of chestnut tannin on the fermentability of soyabean meal nitrogen in the rumen. Annales de Zootechnie, INRA/EDP Sciences, 42(2), 127-127. Reciperado de https://hal. archives-ouvertes.fr/hal-00888877
Mezzomo, R., Paulino, P. V. R., Detmann, E., Valadares, S. C., F ${ }^{\circ}$, Paulino, M. F., Monnerat, J. P. I. S.,... Moura, L. S. (2011). Influence of condensed tannin on intake, digestibility, and efficiency of protein utilization in beef steers fed high concentrate diet. Livestock Science, 141(1), 1-11. doi: 10.1016/j. livsci. 2011.04.004

Nakamura, T., Klopfenstein, T. J., Owen, F. G., Britton, R. A., Grant, R. J., \& Winowiski, T. S. (1992). Nonenzymatically browned soybean meal for lactating dairy cows. Journal of Dairy Science, $75(12)$, 3519-3523. doi: 10.3168/jds.S00220302(92)78127-2

National Research Council (2001). Nutrient requirements of dairy cattle. Washington, D.C.: National Academy Press.

Nocek, J. E. (1997). In situ e outros métodos para estimar a proteína ruminal e a digestibilidade da energia: Revisão. Anais do Simpósio Internacional de Digestibilidade em Ruminantes, Lavras, MG, Brasil.

Orskov, E. R., \& McDonald, I. (1979). The estimation of protein degradability in the rumen from incubation measurements weighted according to rate of passage. The Journal of Agricultural Science, 92(2), 499-508. doi: 10.1017/S0021859600063048

Powell, J. M., Aguerre, M. J., \& Wattiaux, M. A. (2011). Dietary crude protein and tannin impact dairy manure chemistry and ammonia emissions from incubated soils. Journal of Environmental Quality, 40(6), 1767-1774. doi: 10.2134/jeq2011.0085

Santos, F. A. P., Santos, J. E. P., Theurer, C. B., \& Huber, J. T. (1998). Effects of rumen-undegradable protein on dairy cow performance: a 12-year literature review. Journal of Dairy Science, 81(12), 3182-3213. doi: 10.3168/jds.S0022-0302(98)75884-9

Statistical Analysis System Institute (1993). SAS/ STAT user's Guide: statistics. North Caroline: SAS Institute.

Van Soest, P. J., Roberttson, J. B., \& Lewis, B. A. (1991). Methods for dietary fiber, neutral detergent fiber and non starch polysaccharides in relation to animal nutrition. Journal of Dairy Science, 74(10), 35833597. doi: 10.3168/jds.S0022-0302(91)78551-2 
